\title{
The evaluation of hearing functions in patients with childhood vitiligo: are melanocytes involved in the inner ear?
}

\section{Çocukluk çağı vitiligosu olan hastalarda işitme fonksiyonlarının değerlendirilmesi: iç kulaktaki melanositler etkileniyor mu?}

\author{
Osman Caglar Cevik ${ }^{1}$, Arzu Aydin Capkin ${ }^{1}$, Ahmet Arslan $^{2}$, Neslihan Kul$^{2}$, Deniz Aksu Arica ${ }^{1}$
}

${ }^{1}$ Dept. of Dermatology, Karadeniz Technical University, Faculty of Medicine, Trabzon, Turkey, ${ }^{2}$ Dept. of Otorhinolaryngology, Karadeniz Technical University, Faculty of Medicine, Trabzon, Turkey

\begin{abstract}
Background Vitiligo is a common pigment disorder characterized by destruction of melanocytes in epidermis. The inner ear is also one of the remarkable sites of melanocytes. The mechanism destroying the melanocytes in vitiligo may also affect other melanocyctic organs. Several studies have been reported some hearing abnormalities in patients with vitiligo.
\end{abstract}

Objective The purpose of the study is to evaluate the hearing functions with transient-evoked otoacoustic emission (TOAE) test according to the clinical types, disease activity, localization at onset, age at onset, and duration of the disease in the children with vitiligo.

Methods Thirty-five patients with childhood vitiligo (18 females and 17 males, mean age 9.71 \pm 3.75 ) and a healthy control group consisting 35 children (18 females and 17 males, mean age $9.23 \pm 3.40$ ) were consecutively enrolled to this prospective study. Clinical characteristics of the disease including types, activity, localization at onset, age at onset and duration were noted. Auditory functions of children with vitiligo and healthy controls were measured by TOAE test. Test results were compared between vitiligo and control group, and in subgroups of vitiligo patients according to disease characteristics.

Results There were no statistically significant differences between the childhood vitiligo group and control group when TOAE test results compared ( $>>0.05)$. Children with disease onset at the head and neck had significantly higher TOAE test results including in the right ear at a frequency of $4 \mathrm{KHz}$ and average frequency, while compared to the children with disease onset at other areas, respectively $(\mathrm{p}=0.012, \mathrm{p}=0.034)$. There was no statistically significant differences, while TOAE results of subgroups compared according to clinical types, activity, and duration of the disease in the patients with vitiligo ( $\mathrm{p}>0.05)$.

Conclusions According to the our study, which is the first one measures the auditory functions by TOAE in children with vitiligo, TOAE test results did not differ from healthy controls. Although the melanocytes are present in the inner ear, our findings suggest that auditory functions of children with vitiligo are not affected.

Key words: vitiligo, childhood vitiligo, hearing, transient-evoked otoacoustic emission

Corresponding author: Deniz Aksu Arica, Dept. of Dermotology, Karadeniz Technical University, Faculty of Medicine, Trabzon, Turkey Phone: +90 4623775127 E-mail: drdenizaksu@gmail.com

Received: 29 September 2018 Accepted: 2 October 2018

Conflicts of Interest: None 


\section{O̊zet}

Vitiligo, epidermiste melanositlerin yıkımı ile karakterize olan yaygın bir pigmentasyon hastalığıdır. İç kulak da melanositlerin bulunduğu dikkat çekici yerlerdendir. Vitiligoda melanositleri yok eden mekanizma, diğer melanositik organları da etkileyebilir. Çeşitli çalışmalarda vitiligo hastalarında bazı işitme bozuklukları bildirilmiştir.

Amaç $\mathrm{Bu}$ çalışmanın amacı, vitiligolu çocuklarda klinik tiplere, hastalık aktivitesine, başlangıç lokalizasyonuna, başlangıç yaşına ve hastalığın süresine göre transient-uyarılmış otoakustik emisyon (TOAE) testi ile işitme fonksiyonlarını değerlendirmektir.

Yöntem Prospektif çalışmaya çocukluk çağı vitiligosu olan otuz beş çocuk (18 kız, 17 erkek, ort. yaş $9.71 \pm$ 3.75) ve kontrol grubu olarak 35 sağlıklı çocuk (18 kız, 17 erkek, ort. yaş $9.23 \pm 3.40$ ) dahil edildi. Hastalığın tipleri, aktivite, başlangıçtaki lokalizasyon, başlangıç yaşı ve süre dahil olmak üzere hastalığın klinik özellikleri kaydedildi. Vitiligolu çocukların ve sağlıklı kontrollerin işitsel fonksiyonları TOAE testi ile değerlendirildi. Test sonuçları, vitiligo ve kontrol grubu arasında, ve ayrıca vitiligo hastalarının alt gruplarında hastalık özelliklerine göre karşılaştırıldı.

Bulgular Çocukluk çağı vitiligo grubu ile kontrol grubu arasında TOAE testi sonuçları açısından istatistiksel olarak anlamlı fark bulunmadı ( $>0.05)$. Baş ve boyunda hastalık başlangıcı olan çocuklar, sağ kulakta, $4 \mathrm{KHz}$ frekansında ve ortalama frekansta, diğer alanlarda hastalık başlangıcı olan çocuklara göre anlamlı olarak daha yüksek TOAE test sonuçlarına sahipti $(\mathrm{p}=0.012, \mathrm{p}=0.034)$. TOAE sonuçları, vitiligonun klinik tipleri, aktivite ve hastalık süresine göre alt gruplarında karşılaştırıldığında istatistiksel olarak anlamlı fark saptanmadı ( $>0.05)$. Sonuçlar Vitiligolu çocuklarda işitsel fonksiyonları TOAE testi ile ilk olarak değerlendiren çalışmamıza göre, TOAE testi sonuçları sağlıklı kontrollerden farklı değildi. Her ne kadar melanositler iç kulakta mevcut olsa da, bulgularımız vitiligolu çocukların işitsel işlevlerinin etkilenmediğini göstermektedir.

Anahtar kelimeler: vitiligo, çocukluk çağı vitiligosu, işitme, transient-uyarılmıs otoakustik emisyon

\section{Introduction}

Vitiligo is a common acquired pigment disorder characterized by depigmented white macules and patches with an unknown etiology. It affects all ethnic groups and has no sex predilection. The onset is in first two decades in nearly half of the patients. ${ }^{1}$

Melanocytes, the targeted epidermal cells in vitiligo, are also present in the inner ear, and they are thought to have critical roles for normal cochlear function. There are many melanocytes in the human cochlea, particularly in the stria vascularis, modilous, osseous spiral lamina, Reissner's membrane., ${ }^{2,3}$ Although the exact roles of them remains controversial, they are believed to have roles in the maintenance of normal function of the stria vascularis, for the development of the endolymphatic potentials, and for preserving the ion and fluid gradient between the endolymph and perilymph, all of which are critical for normal cochlear function and sensory haircell survival. ${ }^{4}$ Outer hair cells of cochlea act as an amplifier that gives the cochlea its sharp frequency selectivity. Otoacoustic emissions (OAEs) are sounds generated from the outer hair cells as a by-product of their cochlear amplifier function. The presence of OAEs indicates normal functions of these cells and that other structures critical for those functions, such as the stria vascularis, are intact. ${ }^{2,5}$

Since vitiligo affects melanocytes and production of melanin, it has been hypothesized it could also lead to cochlear abnormalities and subsequently to sensorineural hearing loss. ${ }^{4,6}$ Although some reports did not support this hypothesis ${ }^{7}$, several clinical studies had shown significant sensorineural hearing loss in patients with vitiligo.$^{8-9}$ In one of them, by using transient-evoked otoacoustic emission (TOAE) test, Angrisani et $\mathrm{al}^{9}$ found a greater predisposition to cochlear dysfunction, particularly in males. We aimed to evaluate the functions of the outer hair cells in the inner ear, by using transient-evoked otoacoustic emission (TOAE) test according to the clinical types, disease activity, localization at onset, age at onset, and duration of of the disease in the children with vitiligo. 


\section{Patients And Methods}

The study was approved by Karadeniz Technic University faculty of Medicine Ethics Committee (approval number: 59). The procedures were explained to all patients, and their parents, and written informed consents were obtained from the parents.

Thirty-five patients with childhood vitiligo (ranged 0 -16) (18 females and 17 males, mean age $9.71 \pm 3.75$ ) and a sex- and age-matched healthy control group consisting 35 children (18 females and 17 males, mean age $9.23 \pm 3.40$ ) were consecutively enrolled to this prospective case-control study. Exclusion criteria included: a history or any evidence of autological disease, familial hearing loss, oral medications related to possible autotoxicity, chronic noise exposure.

Clinical characteristics of the disease including types, activity, localization at onset, age at onset and duration were noted in the patient group. Regarding to clinical types, the patients were first divided into two part as generalized or non-generalized, then patients in non-generalized group were subsequently divided into subtypes as segmental, acrofacial, focal and universal. For detecting clinical activity, we evaluated the increase in last three months. The patients with increasing lesions were accepted as "active".

Auditory functions of children with vitiligo and healthy controls were measured by TOAE test. The emission values of each frequency range $(1 \mathrm{KHz}, 1.5 \mathrm{KHz}, 2 \mathrm{KHz}, 3$ $\mathrm{KHz}$, and $4 \mathrm{KHz}$ ) and an average emission values were determined in both ears of the patient and control group with the TOAE device.

Test results were compared between vitiligo and control group, and in subgroups of vitiligo patients according to disease characteristics.

Statistical analysis Analysis of the obtained data was performed by using "SPSS for Windows 15.0" program in computer. Statistical evaluation of the data was calculated by using and Chi-square, Mann Whitney U test tests. The significance value (p) was accepted as 0.05 .

\section{Results}

Of the 35 patients and 35 controls included study, 18 (51.4\%) were female and 17 (48.6\%) were male, respectively. The age of patients ranged from 2 to 16. In the control group, it ranged from 6 to 16. The mean ages of two group were $9.71 \pm 3.75$ and $9.23 \pm 3.40$, respectively. The clinical characteristics of patients with vitiligo were listed in table 1.

Table 1. Clinical characteristics of children with vitiligo $(n=35)$

\begin{tabular}{ll}
\hline & Patients with vitiligo, n (\%) \\
Clinical type & \\
Generalized & $11(57.1)$ \\
Focal & $3(8.6)$ \\
Acrofacial & $1(2.9)$ \\
Segmental & $0(0.0)$ \\
Universal & \\
Localization at onset & $10(28.6)$ \\
Head and neck & $15(42.9)$ \\
Trunk & $2(5.7)$ \\
Upper extremity & $8(22.8)$ \\
Lower extremity & $0(0.0)$ \\
Perineum & \\
Clinical activity & $22(62.9)$ \\
Active & $13(37.1)$ \\
Stable & $7(20.0)$ \\
Poliosis & $4(11.4)$ \\
Halo nevi & $2(5.7)$ \\
Mucosal involvement & $4(11.4)$ \\
Vitiligo in family history & $1(2.9)$ \\
Autoimmune diseases in history & $17(48.6)$ \\
Autoimmune diseases in family history & \\
\hline &
\end{tabular}

Auditory functions of children with vitiligo and healthy controls were compared using by TOAE test results in each frequency range $(1 \mathrm{KHz}, 1.5 \mathrm{KHz}, 2 \mathrm{KHz}, 3 \mathrm{KHz}$, and $4 \mathrm{KHz}$ ) and an average emission values. Test results were compared between vitiligo and control group, and in subgroups of vitiligo patients according to disease 
Table 2. Comparison of transient-evoked otoacoustic emission test results of patients with childhood vitiligo and healthy controls

\begin{tabular}{lccc}
\hline Frequency & $\begin{array}{c}\text { Vitiligo }(\mathrm{n}=35) \\
(\mathrm{dB} \text { mean } \pm \mathrm{SD})\end{array}$ & $\begin{array}{c}\text { Controls }(\mathrm{n}=35) \\
(\mathrm{dB} \text { mean } \pm \text { SD })\end{array}$ & $\mathrm{p}$ \\
$1 \mathrm{KHz} \mathrm{L}$ & $7.79 \pm 6.00$ & $10.03 \pm 5.19$ & 0.104 \\
$1 \mathrm{KHz} \mathrm{R}$ & $7.46 \pm 4.92$ & $9.84 \pm 6.81$ & 0.128 \\
$1.5 \mathrm{KHz} \mathrm{L}$ & $7.78 \pm 7.19$ & $7.87 \pm 4.76$ & 0.950 \\
$1.5 \mathrm{KHz} \mathrm{R}$ & $8.01 \pm 6.38$ & $8.16 \pm 6.04$ & 0.924 \\
$2 \mathrm{KHz} \mathrm{L}$ & $6.89 \pm 6.89$ & $6.63 \pm 4.68$ & 0.856 \\
$2 \mathrm{KHz} \mathrm{R}$ & $8.60 \pm 5.49$ & $7.86 \pm 4.52$ & 0.542 \\
$3 \mathrm{KHz} \mathrm{L}$ & $9.45 \pm 7.16$ & $8.95 \pm 4.09$ & 0.721 \\
$3 \mathrm{KHz} \mathrm{R}$ & $9.94 \pm 5.87$ & $9.43 \pm 4.76$ & 0.694 \\
$4 \mathrm{KHz} \mathrm{L}$ & $9.84 \pm 6.98$ & $11.78 \pm 6.24$ & 0.225 \\
$4 \mathrm{KHz} \mathrm{R}$ & $10.66 \pm 7.06$ & $12.23 \pm 4.91$ & 0.292 \\
$\mathrm{AL}$ & $17.32 \pm 5.75$ & $19.24 \pm 4.11$ & 0.113 \\
$\mathrm{AR}$ & $17.79 \pm 5.32$ & $19.24 \pm 4.63$ & 0.230 \\
\hline
\end{tabular}

L: Left, R:Right, dB: Decibel

characteristics. There was no statistically significant differences between the vitiligo group and control group when TOAE test results compared in each frequencies ( $>0.05)$ (Table 2). Additionally, there was no significant differences when TOAE test results of subgroups compared in each frequencies according to clinical types, duration and activity of the disease in the patients with vitiligo $(p>0.05)$. Children with disease onset at the head and neck had significantly higher TOAE test results including in the right ear at a frequency of $4 \mathrm{KHz}$ and average frequency, while compared to the children with disease onset at other areas, respectively $(\mathrm{p}=0.012$, $\mathrm{p}=0.034$ ) (Table 3).

\section{Discussion}

In our study, we evaluated the functions of the outer hair cells in the inner ear, by using transient-evoked otoacoustic emission (TOAE) test according to the clinical types, disease activity, localization at onset, age at onset, and duration of the disease in the children with vitiligo. According to the results of our study, which is the first one measures the auditory functions by TOAE in children with vitiligo, TOAE test results did not differ from healthy controls. We found that children with disease onset at the head and neck had significantly higher TOAE test results including in the right ear at a frequen-

Table 3. Comparison of transient-evoked otoacoustic emission test results according to localization at onset in the patient with vitiligo

\begin{tabular}{lccc}
\hline \multicolumn{1}{c}{ Frequency } & $\begin{array}{c}\text { Head and neck } \\
(\mathrm{dB} \text { mean } \pm \mathrm{SD})\end{array}$ & $\begin{array}{c}\text { Other sites } \\
(\mathrm{dB} \text { mean } \pm \mathrm{SD})\end{array}$ & $\mathrm{p}$ \\
$1 \mathrm{KHz} \mathrm{L}$ & $8.54 \pm 5.13$ & $7.79 \pm 6.38$ & 0.559 \\
$1 \mathrm{KHz} \mathrm{R}$ & $8.54 \pm 4.13$ & $7.29 \pm 5.23$ & 0.380 \\
$1.5 \mathrm{KHz} \mathrm{L}$ & $9.24 \pm 7.23$ & $7.20 \pm 7.24$ & 0.361 \\
$1.5 \mathrm{KHz} \mathrm{R}$ & $10.06 \pm 5.08$ & $7.20 \pm 6.74$ & 0.258 \\
$2 \mathrm{KHz} \mathrm{L}$ & $7.51 \pm 7.21$ & $6.64 \pm 6.89$ & 0.715 \\
$2 \mathrm{KHz} \mathrm{R}$ & $10.13 \pm 4.38$ & $7.99 \pm 5.85$ & 0.290 \\
$3 \mathrm{KHz} \mathrm{L}$ & $11.24 \pm 8.36$ & $8.74 \pm 6.68$ & 0.235 \\
$3 \mathrm{KHz} \mathrm{R}$ & $12.40 \pm 6.13$ & $8.93 \pm 5.56$ & 0.121 \\
$4 \mathrm{KHz} \mathrm{L}$ & $9.76 \pm 8.53$ & $9.88 \pm 6.46$ & 0.520 \\
$4 \mathrm{KHz} \mathrm{R}$ & $16.12 \pm 7.22$ & $8.51 \pm 5.82$ & 0.012 \\
$\mathrm{AL}$ & $18.37 \pm 5.85$ & $16.90 \pm 5.78$ & 0.454 \\
$\mathrm{AR}$ & $20.90 \pm 5.19$ & $16.55 \pm 4.94$ & 0.034 \\
\hline
\end{tabular}

L: Left, R:Right, dB: Decibel

cy of $4 \mathrm{KHz}$ and average frequency, while compared to the children with disease onset at other areas. However, there were no statistically significant differences, while TOAE results of subgroups compared according to clinical types, activity, and duration of the disease in the patients with vitiligo. Although the melanocytes are present in the inner ear, our findings suggest that auditory functions of children with vitiligo are not affected.

Although the exact roles of them remains controversial, melanocytes in the human cochlea, particularly in the stria vascularis, modilous, osseous spiral lamina, Reissner's membrane are thought to have critical roles for normal cochlear function., ${ }^{2,3}$ They are believed to have 
roles in the maintenance of normal function of the stria vascularis, for the development of the endolymphatic potentials, and for preserving the ion and fluid gradient between the endolymph and perilymph, all of which are critical for normal cochlear function and sensory haircell survival. ${ }^{4,10}$

Vitiligo affects melanocytes and production of melanin, so it has been hypothesized that it could also lead to melanocyte destruction systemically, e.g. cochlear abnormalities and subsequently to sensorineural hearing loss. ${ }^{6,11}$ Several studies which evaluated hearing functions in patients with vitiligo yielded different results. Tosti et al. found that $16 \%$ of the patients with vitiligo $(n=50)$ had sensorineural hypoacusis. ${ }^{12}$ In a study investigating the hearing functions in patients with vitiligo by Ozuer et al did not detect any differences compared by control group. ${ }^{13}$ In a different study, with a small patient group, Ardiç et al showed significant hearing loss, particularly in males. ${ }^{14}$ Aydogan et al also found 14\% mild sensorineural hypoacusis in 57 patients with active vitiligo. ${ }^{8}$ In another study from Korea including 89 patients with vitiligo, significant hearing loss has been defined in the patients with active disease. ${ }^{15}$

Otoacoustic emissions are sounds generated from the cochlea caused by the activity of the outer hairy cells and therefore they indicate only the motor function of the cochlea. Otoacoustic emissions recorded after shortterm acoustic stimuli are called transient otoacoustic emissions (TOAE), and they are especially suitable for general monitorization of cochlear functions as a shortterm, easy-to-use, objective method. Its sensitivity is above $90 \%{ }^{15}$

To our knowledge, there are two clinical studies which evaluated the auditory functions in patients with vitiligo by transient otoacoustic emission measurements. In both studies, the patient group mainly consisted of adult patients. Angrisani et al reported that 17 of 24 patients $(70.8 \%)$ had failures according to TOAE results, and 3 of them (12.5\%) had hearing loss. No statistically significant relationship was found between age, type of the disease, duration of the disease and TOAE results in patients with vitiligo. ${ }^{9}$ In another study, by Aslan et al, 36.4\% of the patients had hearing loss in their pure tone audiometry. In TOAE results, a statistically significant decrease was observed in $4 \mathrm{KHz}$ frequency. No significant relationship was found between the age of the patients, disease activity, the clinical type of the disease and TOAE results. ${ }^{16}$

In our study, no significant hearing loss was detected in any of our patients. In those two studies ${ }^{9,16}$, hearing abnormalities were detected especially at high frequencies $(4 \mathrm{KHz})$. In our study, the TOAE results did not show any significant differences with the control group. The main difference of our study from those two studies was the age range of the patients. The study group included patients with childhood vitiligo. We also conducted our study in a larger group of patients than those studies. In our study, there was no statistically significant differences, while TOAE results of subgroups compared according to clinical types, activity, and duration of the disease in the patients with vitiligo.

We aimed to eliminate the possibility of hearing loss secondary to age-related noise by forming our patient with childhood vitiligo. Although significant hearing loss in adult patients with vitiligo were found in both study by TOAE tests ${ }^{9,16}$, no significant hearing loss was found in our larger pediatric patient group by TOAE tests. Moreover, one of the striking result of our study is about the relationship of the initial localization of the disease and TOAE measurements. We found that the hearing functions of children with vitiligo with the onset of the head and neck region were found to be better than those children who had disease with an onset in the trunk or extremities according to $4 \mathrm{KHz}$ frequency and average TOAE results. In other words, onset at the head and neck area did not cause a worse TOAE result in patients with childhood vitiligo. It may be speculated that melanocyte destruction in the epidermis in a close localization may not affect the melanocytes in the inner ears.

In conclusion, in our study, which is the first one measures the auditory functions by TOAE in children with vitiligo, hearing functions did not differ from healthy controls. Although the melanocytes are present in the 
inner ear, our findings suggest that auditory functions of children with vitiligo are not affected. Since the exact role of the melanocytes in the inner ear is still controversial, more studies are needed to reveal their possible functions.

\section{References}

1. Iannella G, Greco A, Didona D, et al. Vitiligo: Pathogenesis, clinical variants and treatment approaches. Autoimmun Rev 2016;15:335-43.

2. Anbar TS, El-Badry MM, McGrath JA, Abdel-Azim ES. Most individuals with either segmental or non-segmental vitiligo display evidence of bilateral cochlear dysfunction. Br J Dermatol 2015;172:406-11.

3. La Ferriere KA, Arenberg IK, Hawkins JE Jr, Johnsson LG. Melanocytes of the vestibular labyrinth and their relationship to the microvasculature. Ann Otol Rhinol Laryngol 1974;83:685-94.

4. Tachibana M. Sound needs sound melanocytes to be heard. Pigment Cell Res 1999;12:344-54.

5. Prieve B, Fitzgerald S. Otoacoustic emissions. In: Handbook of Clinical Audiology. (Katz J, eds), Lippincot Williams and Wilkins 2003;440-60.

6. Kovasc SO. Vitiligo. J Am Acad Dermatol 1998;38:64766.

7. Escalente-Ugalde C, Poblano A, Montes de Oca E, et al. No evidence of hearing loss in patients with vitiligo. Arch Dermatol 1991;127:1240.

8. Aydogan K, Turan OF, Onart S, et al. Audiological abnormalities in patients with vitiligo. Clin Exp Dermatol 2006;31:110-3.

9. Angrisani RMG, Azevedo FM, Pereira LD, et al. A study on otoacoustic emisions and supression effects in patients with vitiligo. Braz J Otorhinolaryngol 2009;75:111-5.

10. Cuesta SM, Contreras J, Zurita E, et al. Melanin precursors prevent premature age-related and noise-induced hearing loss in albino mice. Pigment Cell Melanoma Res 2009;23:72-83.

11. Huggins RH, Janusz CA, Schwartz RA. Vitiligo: A sign of systemic disease. Indian J Dermatol Venereol Leprol 2006;72:68-71.

12. Tosti A, Bardazzi F, Tosti G, et al. Audiologic abnormalities in cases vitiligo. J Am Acad Dermatol 1987;17:230-3.

13. Ozer MZ, Sahiner T, Aktan S, et al. Auditory evoked potentials in vitiligo patients. Scand Audiol 1998;27:255-8.

14. Ardic FN, Aktan S, Kara CO, et al. High-frequency hearing and reflex latency in patients with pigment disorder. Am J Otolaryngol 1998;19:365-9.

15. Hong CK, Lee MH, Jeong KH, et al. Clinical analysis of hearing levels in vitiligo patients. Eur J Dermatol 2009;19:50-6.

16. Aslan S, Serarslan G, Teksoz E, Dagli S. Audiological and transient evoked otoacoustic emission findings in patients with vitiligo. Otolaryngol Head and Neck Surg 2010;142:409-15. 